\title{
Duodenal Implications in the Pathophysiology of Functional Dyspepsia
}

\author{
Kwang Jae Lee, MD, PhD ${ }^{1}$ and Jan Tack, MD, PhD ${ }^{2 *}$ \\ ${ }^{1}$ Department of Gastroenterology, Ajou University School of Medicine, Suwon, Korea, ${ }^{2}$ Division of Gastroenterology, Department of Internal \\ Medicine, University of Leuven, Leuven, Belgium
}

Functional dyspepsia (FD) is a heterogeneous disorder associated with diverse pathophysiologic mechanisms. Studies have shown duodenal implications in the pathophysiology of FD. Duodenal hypersensitivity to acid, increased duodenal acid exposure, and abnormal responses to duodenal lipids or released cholecystokinin have been observed in patients with FD. Moreover, there is evidence indicating duodenal immune activation in FD. Alterations in the number of duodenal eosinophils or intraepithelial lymphocytes have been reported in a subset of FD patients, particularly in patients with post-infectious FD. Whether these abnormalities in the duodenum play a crucial role in the generation of dyspeptic symptoms needs to be elucidated. Further investigations on the relationship between duodenal abnormalities and well-known pathophysiologic mechanisms of FD are required. Furthermore, the causative factors related to the development of duodenal abnormalities in FD warrant further study.

(J Neurogastroenterol Motil 2010;16:251-257)

Key Words

Acids, Duodenum, Dyspepsia, Eosinophilia

\section{Introduction}

Functional dyspepsia (FD) is a heterogeneous disorder characterized by the presence of recurrent or persistent symptoms thought to originate in the gastroduodenal region without any organic, systemic or metabolic disease that is likely to explain the symptoms. ${ }^{1}$ The pathophysiology of FD is considered to be multifactorial and not completely understood. Diverse pathophysiologic mechanisms have been suggested to be involved in FD. Several mechanisms have been proposed to be of importance, such as delayed gastric emptying, impaired proximal gastric ac- commodation to a meal, gastric hypersensitivity to distension, abnormal duodenojejunal motility, and psychological disturbance. ${ }^{2-6}$

The stomach is traditionally believed to be mainly responsible for the genesis of dyspeptic symptoms. More recent studies have shown a number of sensorimotor and structural duodenal abnormalities in FD. Abnormal motor and sensory responses to duodenal acid or lipids have been demonstrated in patients with FD. ${ }^{7-11}$ Duodenal eosinophilia has been reported in FD patients. ${ }^{12}$ Focal T-cell aggregates, decreased CD4 + cells and increased macrophage counts have been observed in the duodenum of patients with presumed post-infectious FD (PI-FD), which indicates impaired ability of the immune system to terminate the in-

Received: April 1, 2010 Revised: June 12, 2010 Accepted: June 16, 2010

(c) This is an Open Access article distributed under the terms of the Creative Commons Attribution Non-Commercial License (http://creativecommons. org/licenses/by-nc/3.0) which permits unrestricted non-commercial use, distribution, and reproduction in any medium, provided the original work is properly cited.

*Correspondence: Jan Tack, MD, PhD

Center for Gastroenterological Research, Catholic University of Leuven, Leuven B-3000, Belgium

Tel: +32-16-34-5761, Fax: +32-16-34-5939, E-mail: jan.tack@med.kuleuven.be

Financial support: None.

Conflicts of interest: None. 
flammatory response after acute insult. ${ }^{13}$ These studies suggest the possibility that the duodenum is involved in the pathophysiology of FD. Thus, in the present review, we aimed to address duodenal implications in the pathophysiology of FD.

\section{Abnormal Responses to Duodenal Acid in FD}

The majority of FD patients have normal acid secretion, ${ }^{14}$ and gastric sensitivity to acid does not seem to be abnormal in those patients. ${ }^{15}$ However, acid suppressive therapy provides symptomatic relief in a subset of FD patients. ${ }^{16}$ Generally, acid suppressive therapy using proton-pump inhibitors seems beneficial to the patients whose predominant symptoms are epigastric pain, burning sensation or gastroesophageal reflux symptoms. Samsom et al. ${ }^{7}$ reported that duodenal acid infusion induced nausea in a subset of FD patients, but not in healthy controls, suggesting the presence of duodenal hypersensitivity to acid in FD patients. However, other studies found that dyspeptic symptoms such as nausea could be induced by duodenal acidification in healthy volunteers. Duodenal acid perfusion $(0.2 \mathrm{~N}, 5 \mathrm{~mL} / \mathrm{min})$ for 15 minutes significantly increases symptom scores of discomfort, bloating, nausea, and epigastric burning in healthy subjects, compared with saline infusion. ${ }^{17}$ Similarly, it has been demonstrated that dyspeptic symptoms including fullness, bloating, nausea, satiety, epigastric burning and epigastric pain are induced by duodenal acid infusion in healthy volunteers. ${ }^{18}$ In FD patients with prominent nausea, no significant differences in dyspeptic symptom scores were observed before and after duodenal acid infusion, and between duodenal saline and acid infusion. ${ }^{8}$ Therefore, studies on the presence of duodenal hypersensitivity to acid in FD patients and its role in the pathophysiology of FD remain controversial. Since the number of study subjects in previous studies is small, larger studies are required.

A 24-hour ambulatory duodenal $\mathrm{pH}$ monitoring has shown increased spontaneous duodenal acid exposure in FD patients. ${ }^{8,19}$ Duodenal acid exposure is reported to be significantly increased in FD patients during the daytime and after a meal. FD patients with increased spontaneous duodenal acid exposure have more severe dyspeptic symptoms than FD patients with normal duodenal acid exposure. ${ }^{8}$ The possible mechanisms underlying increased duodenal acid exposure present in a subset of FD patients include impaired duodenal acid neutralization and reduced duodenal acid clearance. Information on duodenal acid neutralization in FD patients is lacking. Whereas, reduced duodenal acid clearance due to a decreased duodenal motor response to acid has been demonstrated in FD patients. ${ }^{7,8}$ Thus, reduced duodenal acid clearance seems to play a role in increasing duodenal acid exposure in $\mathrm{FD}$ patients.

The mechanism through which increased duodenal acid exposure contributes to the generation of dyspeptic symptoms remains to be elucidated. $\mathrm{H}^{+}$stimulates acid sensors such as transient receptor potential vanilloid 1 on the afferent nerves in the duodenum, followed by the release of calcitonin gene-related peptide and nitric oxide. ${ }^{20}$ Therefore, acid can directly stimulate chemosensitive afferent pathways from the duodenum. Given that chemical stimulation is able to induce sensitization at the peripheral or the spinal level, ${ }^{21}$ stimulation of duodenal afferents by acid may enhance gastric mechanosensitivity through the induction of spinal sensitization. Indeed, a barostat study during duodenal infusion of saline or acid in healthy subjects revealed that duodenal acid infusion increased gastric mechanosensitivity. $^{22}$

Intraduodenal acid infusion induces an enterogastric feedback, which suppresses propagated antral waves, stimulates isolated pyloric pressure waves and delays gastric emptying. ${ }^{23-25}$ The greater the concentration of acid in the duodenum, the greater is the inhibition of gastric emptying. ${ }^{26}$ Accordingly, it is conceivable that increased duodenal acid exposure results in excessive enterogastric feedback and delays gastric emptying. On the other hand, duodenal $\mathrm{pH}$ influences the regularity of the migrating motor complex and alkaline $\mathrm{pH}$ is needed for the initiation of a phase III. ${ }^{27}$ Thus, prolonged duodenal acidification might inhibit the occurrence of a phase III. A recent study in healthy volunteers showed that duodenal acid perfusion did not affect the occurrence and duration of a phase III but induced antral hypomotility. ${ }^{17}$ These findings suggest that duodenal acidification induces or aggravates dyspeptic symptoms through its effects on gastric motor function.

Therefore, the prolonged duodenal exposure to acid seems to be responsible for the generation of dyspeptic symptoms through the induction of gastric motor and sensory dysfunction.

\section{Abnormal Responses to Duodenal Lipids in FD}

FD patients commonly report exacerbation of dyspeptic symptoms by fatty meals. Postprandial gastric hypersensitivity to distension plays a crucial role in the generation of dyspeptic symptoms in $\mathrm{FD}^{28}$ In contrast to healthy controls, dyspeptic pa- 
tients have increased sensitivity to both gastric distension and intraduodenal lipid. ${ }^{29}$ Most FD patients experienced nausea and bloating during lipid infusion, but remained asymptomatic during saline infusion. Controls reported no symptoms during lipid infusion. $^{29}$ Duodenal lipid infusion can differentiate FD from healthy controls. After lipid infusion, $95 \%$ of $\mathrm{FD}$ patients are outside the normal range of controls for first sensation, bloating and/or discomfort thresholds to gastric distension, compared with $65 \%$ in the fasting state. ${ }^{11}$ Different chemical composition of nutrients in the duodenum results in different sensory responses to gastric distension, which cannot be explained by changes in gastric tone. ${ }^{30}$ Intraduodenal lipid, but not glucose, enhances gastric mechanosensitivity in patients with FD but not in healthy subjects. ${ }^{31}$ Moreover, in FD patients, nausea is more common during lipid than glucose infusion and does not occur during saline. Healthy controls do not experience any symptoms during any infusion. These findings suggest the presence of duodenal hypersensitivity to lipid in FD patients. ${ }^{31}$ Thus, duodenal lipid can be involved in the generation of dyspeptic symptoms through duodenal hypersensitivity to lipid and its enhancing effects on gastric sensitivity.

Long chain and medium chain triglycerides have different effects on perception, gastric tone, and gut hormonal release. Intraduodenal infusion of long chain triglycerides induces satiation, fullness and nausea, reduces gastric tone, and increases plasma levels of cholecystokinin (CCK), gastric inhibitory polypeptide, neurotension, and pancreatic polypeptide. In contrast, intraduodenal infusion of medium chain triglycerides reduces gastric tone, but does not affect perception or plasma gut hormone levels. ${ }^{32}$ Therefore, long chain triglycerides seem to be more potent in inducing symptoms than medium chain triglycerides. Since gastric relaxation per se may occur without significant changes in plasma gut hormone levels and perception, symptoms associated with long chain triglycerides are likely to be attributed to gut hormonal changes including CCK. Indeed, dyspeptic symptoms induced by intraduodenal lipid infusion are alleviated by the CCK-A receptor antagonist dexloxiglumide, ${ }^{33}$ suggesting that $\mathrm{CCK}$ plays a crucial role in inducing sensations associated with intraduodenal lipid. CCK is involved in the control of food intake and the perception of satiety. Moreover, CCK modulates upper gastrointestinal function such as gastric emptying. Accordingly, an altered response to $\mathrm{CCK}$ might lead to gastric motor dysfunction and dyspeptic symptoms. A CCK challenge test has been used to test the response to CCK. The CCK test is considered to be positive when the intravenous CCK-8 infusion reproduces the patients' symptoms, while placebo infusion does not. A previous study has demonstrated that a high proportion of the patients with dysmotility-like FD have an abnormal response to CCK-8 infusion. ${ }^{34}$ This abnormal response to CCK may play a role in the genesis of dyspeptic symptoms in FD.

Therefore, duodenal lipids seem to be responsible for the generation of dyspeptic symptoms in FD through the induction of gastric motor and sensory dysfunction or the altered response to released CCK. Table 1 shows the summary of previous studies

Table 1. Studies on Abnormal Responses to Duodenal Acid or Lipids in Functional Dyspepsia

\begin{tabular}{|c|c|c|c|}
\hline Study & Subjects & Methods & Results \\
\hline \multirow{2}{*}{$\begin{array}{l}\text { Barbera et al, } \\
1995\end{array}$} & \multirow{2}{*}{$\begin{array}{l}10 \mathrm{FD} \text { patients } \\
10 \text { controls }\end{array}$} & Intraduodenal infusion of lipid or saline & \multirow{2}{*}{$\begin{array}{l}\text { In contrast controls, dyspeptic patients } \\
\text { have increased sensitivity to intraduodenal lipid }\end{array}$} \\
\hline & & Evaluation of gastric mechanosensitivity & \\
\hline \multirow{2}{*}{$\begin{array}{l}\text { Barbera et al, } \\
1995\end{array}$} & $18 \mathrm{FD}$ patients & Intraduodenal infusion of lipid or glucose & \multirow{2}{*}{$\begin{array}{l}\text { Intraduodenal lipid but not glucose sensitizes } \\
\text { the stomach to distension in FD patients but } \\
\text { not in controls }\end{array}$} \\
\hline & 9 controls & Evaluation of gastric mechanosensitivity & \\
\hline \multirow{2}{*}{$\begin{array}{l}\text { Samsom et al, } \\
1999\end{array}$} & 12 FD patients & Intraduodenal infusion of acid or saline & \multirow{2}{*}{$\begin{array}{l}\text { Reduced duodenal acid clearance and duodenal } \\
\text { motor activity in FD patients }\end{array}$} \\
\hline & 10 controls & Recording of duodenal pressures and $\mathrm{pH}$ & \\
\hline \multirow{2}{*}{$\begin{array}{l}\text { Feinle et al, } \\
2001\end{array}$} & $6 \mathrm{FD}$ patients & Intraduodenal infusion of lipid or saline & \multirow{2}{*}{$\begin{array}{l}\text { Dexloxiglumide diminishes the effect of duodenal } \\
\text { lipids on gastric compliance and symptoms } \\
\text { in FD patients }\end{array}$} \\
\hline & 6 controls & Administration of the CCK-A antagonist & \\
\hline \multirow{2}{*}{$\begin{array}{l}\text { Björnsson et al, } \\
2003\end{array}$} & $20 \mathrm{FD}$ patients & Intraduodenal infusion of lipid & \multirow{2}{*}{$\begin{array}{l}\text { Duodenal lipid infusion more enhances gastric } \\
\text { mechanosensitivity in FD patients than in controls }\end{array}$} \\
\hline & 13 controls & Evaluation of gastric mechanosensitivity & \\
\hline $\begin{array}{l}\text { Lee et al, } \\
2004\end{array}$ & $11 \mathrm{FD}$ patients & 24-hour ambulatory duodenal $\mathrm{pH}$ monitoring & $\begin{array}{l}\text { Increased spontaneous duodenal acid exposure } \\
\text { in FD patients with prominent nausea }\end{array}$ \\
\hline \multirow{2}{*}{$\begin{array}{l}\text { Bratten et al, } \\
2009\end{array}$} & $34 \mathrm{FD}$ patients & 48-hour ambulatory duodenal $\mathrm{pH}$ monitoring & \multirow{2}{*}{$\begin{array}{l}\text { Greater duodenal acid exposure in FD patients, } \\
\text { compared with controls }\end{array}$} \\
\hline & 25 controls & & \\
\hline
\end{tabular}

$\mathrm{FD}$, functional dyspepsia; CCK, cholecystokinin. 
on abnormal responses to duodenal acid or lipids in FD.

Ghrelin increases appetite and stimulates hunger. Previous studies revealed that ghrelin enhanced gastrointestinal motility and gastric emptying in humans. ${ }^{35-38}$ Plasma ghrelin levels fall following meals, ${ }^{39}$ which may become a satiety signal suppressing food intake. A recent study has shown abnormally low preprandial ghrelin levels and the absence of significant postprandial decrease of ghrelin levels in a subset of dysmotility-like FD patients, ${ }^{40}$ suggesting the role of ghrelin in the pathophysiology of FD. Ghrelin is produced mainly by enteroendocrine cells in the oxyntic glands of the stomach, which seems to be possibly modulated by a vagovagal reflex. However, little is known about the influence of duodenal nutrients on ghrelin secretion, warranting further investigation.

\section{Duodenal Immune Activation in FD}

Eosinophils and mast cells contribute to immune responses or immune activation. Mast cells induce eosoniphil migration and eosinophils activate mast cells. ${ }^{41}$ Mast cells are closely related to enteric nerves in IBS patients ${ }^{42}$ and increased mast cell numbers have been reported in the proximal and distal gut of diarrhea-predominant IBS patients. ${ }^{43,44}$ Activated mast cells release tryptase, histamine and prostaglandin $\mathrm{D}_{2}{ }^{45}$ Mucosal mast cell mediators from IBS patients excite rat nociceptive visceral sensory nerves, which suggests the involvement of mast cells in the mechanism underlying visceral hypersensitivity in IBS. ${ }^{46}$ Degranulation from mast cells and eosinophils leads to neural stimulation and smooth muscle contraction, which in turn results in gastrointestinal symptoms, such as abdominal pain and bloating. ${ }^{47}$ While a significant increase in mast cells has not been observed in the duodenum of patients with FD, duodenal eosinophilia in FD has been described. ${ }^{12,48}$ Higher values of eosinophils are detected in the duodenum of dyspeptic patients, whereas gastric eosinophil counts are not altered in FD. Early satiety is reported to be associated with duodenal eosinophilia, ${ }^{12}$ which should be explained by further studies. The association of mural eosinophilia and symptomatic gastric motor dysfunction has been demonstrated. ${ }^{49}$ Duodenal eosinophilia has not been reported in patients with IBS, while duodenal mast cells are significantly increased in IBS. ${ }^{48}$ Thus, duodenal mast cell hyperplasia seems to be related to IBS and eosinophilia to FD. Eosinophils secrete multiple cytokines, chemokines and neuroactive chemicals. ${ }^{45}$ In animal models, eosinophils have been suggested to cause gastrointestinal dysmotility and impaired gastric relaxation. ${ }^{50,51}$
Whether duodenal eosinophilia in humans can influence gastrointestinal sensory and motor function warrants further investigation. Moreover, the role of duodenal eosinophilia in the genesis of dyspeptic symptoms needs to be further studied.

Like post-infectious IBS, some patients develop FD after an acute gastroenteritis. In a recent study, prevalence of dyspepsia and IBS during a 1-year follow-up in a cohort of adult patients affected by a Salmonella gastroenteritis outbreak was prospectively evaluated. $^{52}$ Both dyspepsia and IBS were significantly more prevalent in exposed subjects compared with unexposed subjects. ${ }^{52}$ These findings suggest development of FD after acute inflammatory insult, which is called PI-FD. An increased number of lamina propria $\mathrm{T}$ cells, mast cells, and enterochromaffin cells have been observed in the colon or ileum of patients who have developed PI-IBS. ${ }^{43,44}$ The mediators released by these activated cells may stimulate sensory afferent pathways and induce visceral hyperalgesia. Whether these inflammatory changes are simultaneously involved in the upper and lower gastrointestinal tract has not been previously studied. PI-FD is associated with persisting focal T-cell aggregates, decreased CD4+ cells and increased macrophages in the duodenum. ${ }^{13}$ Enterochromaffin cell counts are not altered in PI-FD. ${ }^{13}$ Early satiety, weight loss, nausea and vomiting are more frequently reported in patients with presumed PI-FD. ${ }^{53}$ Helicobacter pylori (H. pylori) infection, gastric emptying, and gastric sensitivity do not seem to be associated with PI-FD, whereas a high prevalence of impaired gastric accommodation is observed in patients with presumed PI-FD. ${ }^{54}$ This impairment is suggested to be attributable to a dysfunction at the level of gastric nitrergic neurons. It is conceivable that $H$. pylori infection influences duodenal immune cells. Indeed, the number of duodenal intraepithelial lymphocytes is significantly increased in $H$. pylori positive FD patients due to a higher number of $\mathrm{CD} 8+\mathrm{CD} 3+$ intraepithelial lymphocytes, although there is no change in $H$. pylori negative patients. CD95/Fas and HLA-DR expressing CD3 + intraepithelial lymphocytes show a significant reduction in the $H$. pylori negative FD group. ${ }^{54} H$. $p y$ lori colonization on the gastric mucosa enhances inflammatory cell infiltration, which may persist after the eradication of $H$. pylori. ${ }^{55}$ Whether H. pylori infection could contribute to immune activation observed in the duodenal mucosa of $H$. pylori positive FD patients should be further investigated. The causative factors related to the development of PI-FD and the role of duodenal immune activation in the generation of dyspeptic symptoms need further investigation. Table 2 shows the summary of previous studies on duodenal immune activation in FD. 
Table 2. Studies on Duodenal Immune Activation in Functional Dyspepsia

\begin{tabular}{|c|c|c|c|}
\hline Study & Subjects & Methods & Results \\
\hline $\begin{array}{l}\text { Gargala et al, } \\
2007\end{array}$ & $\begin{array}{l}26 \mathrm{FD} \text { patients } \\
12 \text { controls }\end{array}$ & $\begin{array}{l}\text { Duodenal biopsy } \\
\text { Counts of IELs } \\
\text { in the duodenum }\end{array}$ & $\begin{array}{l}\text { Higher numbers of CD8 + CD3 + IELs in H. pylori }(+) \mathrm{FD} \\
\text { patients and lower numbers of CD95/Fas and HLA-DR } \\
\text { expressing CD3+ IELs in H. pylori (-) FD patients }\end{array}$ \\
\hline $\begin{array}{l}\text { Talley et al, } \\
2007\end{array}$ & $\begin{array}{l}\text { 51 FD patients } \\
48 \text { controls }\end{array}$ & $\begin{array}{l}\text { Duodenal and } \\
\text { gastric biopsy } \\
\text { Eosinophil counts in the } \\
\text { duodenum and stomach }\end{array}$ & $\begin{array}{l}\text { FD patients have duodenal eosinophilia, but normal gastric } \\
\text { eosinophil counts } \\
\text { Early satiety is associated with duodenal eosinophilia. }\end{array}$ \\
\hline $\begin{array}{l}\text { Walker et al, } \\
2009\end{array}$ & $\begin{array}{l}51 \mathrm{FD} \text { patients } \\
48 \text { controls }\end{array}$ & $\begin{array}{l}\text { Duodenal biopsy } \\
\text { Counts of eosinophils } \\
\text { and mast cells }\end{array}$ & Duodenal eosinophilia but no mast cell hyperplasia in FD patients \\
\hline $\begin{array}{l}\text { Kindt et al, } \\
2009\end{array}$ & $\begin{array}{l}12 \text { unspecified-onset } \\
\text { FD } \\
12 \text { PI-FD }\end{array}$ & $\begin{array}{l}\text { Duodenal biopsy } \\
\text { Counts of CD4+, CD } 8+, \\
\text { CD } 68+\text { cells and EC }\end{array}$ & $\begin{array}{l}\text { Persisting focal T-cell aggregates, decreased CD4 }+ \text { cells and } \\
\text { increased macrophage counts in PI-FD } \\
\text { Comparable EC numbers }\end{array}$ \\
\hline
\end{tabular}

FD, functional dyspepsia; PI-FD, post-infectious functional dyspepsia; IELs, intraepithelial lymphocytes; EC, enterochromaffin cells; H. pylori, Helicobacter pylori.

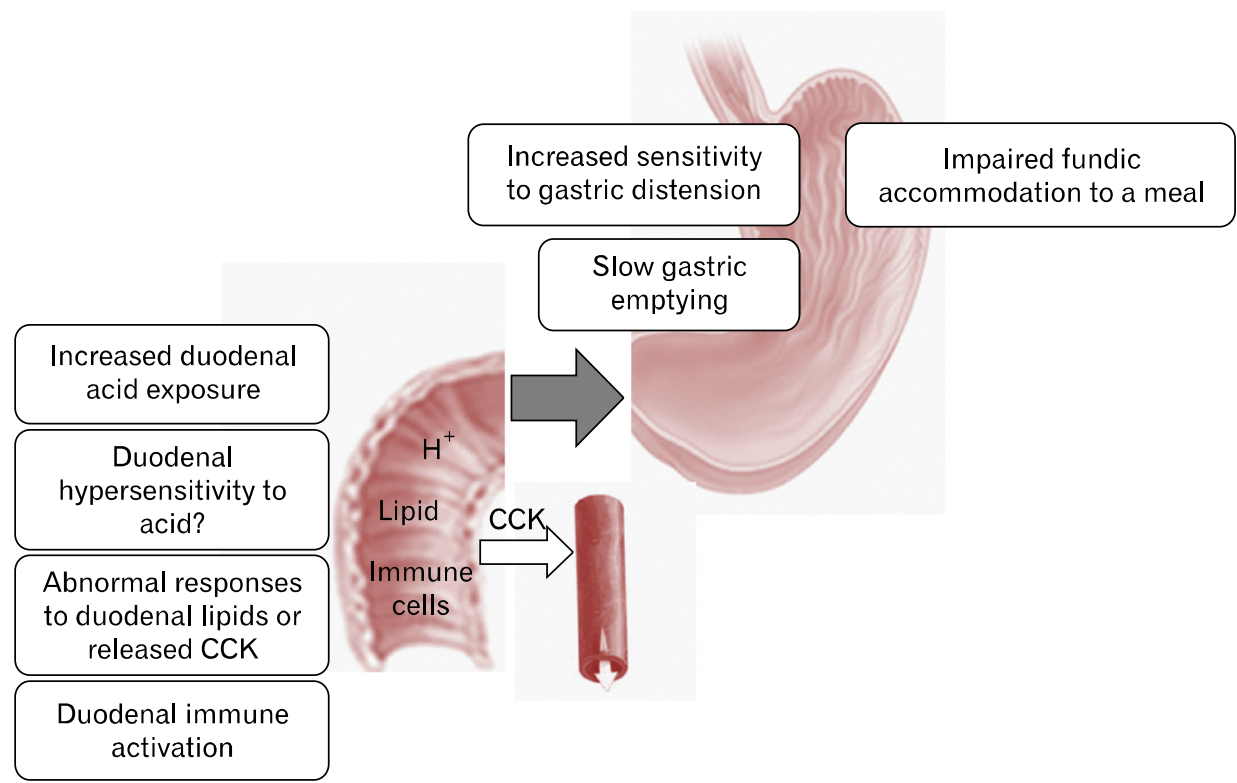

Figure 1. Duodenal implications in the pathophysiology of functional dyspepsia. CCK, cholecystokinin.

\section{Conclusion}

Several recent studies have suggested the involvement of duodenal abnormalities in the pathophysiology of FD. Figure 1 depicts duodenal implications in the pathophysiology of FD. Duodenal abnormalities observed in FD patients include duodenal hypersensitivity to acid, increased duodenal acid exposure, abnormal responses to duodenal lipids or released cholecystokinin, and duodenal immune activation. Whether these abnormalities in the duodenum play a crucial role in the generation of dyspeptic symptoms needs to be further elucidated. Further investigations on the relationship between duodenal abnormal- ities and well-known pathophysiologic mechanisms of FD are required. Furthermore, the causative factors related to the development of duodenal abnormalities in FD warrant further study.

\section{References}

1. Tack J, Talley NJ, Camilleri M, et al. Functional gastroduodenal disorders. Gastroenterology 2006;130:1466-1479.

2. Stanghellini V, Tosetti C, Paternico A, et al. Risk indicators of delayed gastric emptying of solids in patients with functional dyspepsia. Gastroenterology 1996;110:1036-1042.

3. Sarnelli G, Caenepeel P, Geypens B, Janssens J, Tack J. Symptoms 
associated with impaired gastric emptying of solids and liquids in functional dyspepsia. Am J Gastroenterol 2003;98:783-788.

4. Tack J, Piessevaux H, Coulie B, Caenepeel P, Janssens J. Role of impaired gastric accommodation to a meal in functional dyspepsia. Gastroenterology 1998;115:1346-1352.

5. Tack J, Caenepeel P, Fischler B, Piessevaux H, Janssens J. Symptoms associated with hypersensitivity to gastric distention in functional dyspepsia. Gastroenterology 2001;121:526-535.

6. Haug TT, Svebak S, Wilhelmsen I, et al. Psychological factors and somatic symptoms in functional dyspepsia. A comparison with duodenal ulcer and healthy controls. J Psychosom Res 1994;38:281-291.

7. Samsom M, Verhagen MA, vanBerge Henegouwen GP, Smout AJ. Abnormal clearance of exogenous acid and increased acid sensitivity of the proximal duodenum in dyspeptic patients. Gastroenterology 1999;116:515-520.

8. Lee KJ, Demarchi B, Demedts I, Sifrim D, Raeymaekers P, Tack J. A pilot study on duodenal acid exposure and its relationship to symptoms in functional dyspepsia with prominent nausea. Am J Gastroenterol 2004;99:1765-1773.

9. Bratten J, Jones MP. Prolonged recording of duodenal acid exposure in patients with functional dyspepsia and controls using a radiotelemetry pH monitoring system. J Clin Gastroenterol 2009;43: 527-533.

10. Fried $\mathrm{M}$, Feinle $\mathrm{C}$. The role of fat and cholecystokinin in functional dyspepsia. Gut 2002;51(suppl 1):i54-i57.

11. Björnsson E, Sjöberg J, Ringström G, Norström M, Simrén M, Abrahamsson H. Effects of duodenal lipids on gastric sensitivity and relaxation in patients with ulcer-like and dysmotility-like dyspepsia. Digestion 2003;67:209-217.

12. Talley NJ, Walker MM, Aro P, et al. Non-ulcer dyspepsia and duodenal eosinophilia: an adult endoscopic population-based case-control study. Clin Gastroenterol Hepatol 2007;5:1175-1183.

13. Kindt S, Tertychnyy A, de Hertogh G, Geboes K, Tack J. Intestinal immune activation in presumed post-infectious functional dyspepsia. Neurogastroenterol Motil 2009;21:832-e856.

14. Collen MJ, Loebenberg MJ. Basal gastric acid secretion in nonulcer dyspepsia with or without duodenitis. Dig Dis Sci 1989;34:246-250.

15. George AA, Tsuchiyose M, Dooley CP. Sensitivity of the gastric mucosa to acid and duodenal contents in patients with nonulcer dyspepsia. Gastroenterology 1991;101:3-6.

16. Talley NJ, Meineche-Schmidt V, Pare P, et al. Efficacy of omeprazole in functional dyspepsia: double-blind, randomized, placebo-controlled trials (the Bond and Opera studies). Aliment Pharmacol Ther 1998;12:1055-1065.

17. di Stefano M, Vos R, Vanuytsel T, Janssens J, Tack J. Prolonged duodenal acid perfusion and dyspeptic symptom occurrence in healthy volunteers. Neurogastroenterol Motil 2009;21:712-e740.

18. Lee KJ, Kim JH, Cho SW. Dyspeptic symptoms associated with hypersensitivity to gastric distension induced by duodenal acidification. J Gastroenterol Hepatol 2006;21:515-520.

19. Bratten J, Jones MP. Prolonged recording of duodenal acid exposure in patients with functional dyspepsia and controls using a radiotelemetry $\mathrm{pH}$ monitoring system. J Clin Gastroenterol 2009; 43:527-533.

20. Akiba Y, Kaunitz JD. Luminal chemosensing and upper gastrointestinal mucosal defenses. Am J Clin Nutr 2009;90:826S-831S.
21. Mayer EA and Gebhart GF. Basic and clinical aspects of visceral hyperalgesia. Gastroenterology 1994;107:271-293.

22. Lee KJ, Vos R, Janssens J, Tack J. Influence of duodenal acidification on the sensorimotor function of the proximal stomach in humans. Am J Physiol 2004;286:G278-G284.

23. Schwarz MP, Samsom M, Smout AJPM. Chemospecific alterations in duodenal perception and motor response in functional dyspepsia. Am J Gastroenterol 2001;96:2596-2602.

24. Houghton LA, Kerrigan DD, Read NW. Effect of intraduodenal infusion of acid on the antropyloroduodenal motor unit in human volunteers. J Gastrointest Motil 1990;2:202-208.

25. Hunt JN, Knox MT. The slowing of gastric emptying by four strong acids and three weak acids. J Physiol 1972;222:187-208.

26. Lin HC, Doty JE, Reedy TJ, et al. Inhibition of gastric emptying by acids depends on $\mathrm{pH}$, titratable acidity, and length of intestine exposed to acid. Am J Physiol 1990;259:G1025-G1030.

27. Woodtli W, Owyang C. Duodenal $\mathrm{pH}$ governs interdigestive motility in humans. Am J Physiol 1995;268:G146-G152.

28. Lemon M, Dedering JP, Flourie B, et al. Abnormal perception of visceral pain in response to gastric distension in chronic idiopathic dyspepsia. Dig Dis Sci 1991;36:1249-1254.

29. Barbera R, Feinle C, Read NW. Abnormal sensitivity to duodenal lipid infusion in patients with functional dyspepsia. Eur J Gastroenterol Hepatol 1995; 7:1051-1057.

30. Feinle C, Grundy D, Read NW. Effects of duodenal nutrients on sensory and motor responses of the human stomach to distension. Am J Physiol 1997;273:G721-G726.

31. Barbera R, Feinle C, Read NW. Nutrient-specific modulation of gastric mechanosensitivity in patients with functional dyspepsia. Dig Dis Sci 1995;40:1636-1641.

32. Barbera R, Peracchi M, Brighenti F, Cesana B, Bianchi PA, Basilisco G. Sensations induced by medium and long chain triglycerides: role of gastric tone and hormones. Gut 2000;46:32-36.

33. Feinle C, Meier O, Otto B, D'Amato M, Fried M. Role of duodenal lipid and cholecystokinin A receptors in the pathophysiology of functional dyspepsia. Gut 2001;48:347-355.

34. Chua AS, Keeling PW, Dinan TG. Role of cholecystokinin and central serotonergic receptors in functional dyspepsia. World J Gastroenterol 2006;12:1329-1335.

35. Tack J, Depoortere I, Bisschops R, Verbeke K, Janssens J, Peeters T. Influence of ghrelin on gastric emptying and meal-related symptoms in idiopathic gastroparesis. Aliment Pharmacol Ther 2005;22:847853.

36. Tack J, Depoortere I, Bisschops R, et al. Influence of ghrelin on interdigestive gastrointestinal motility in man. Gut 2006;5 5:327-333.

37. Binn M, Albert C, Gougeon A, et al. Ghrelin gastrokinetic action in patients with neurogenic gastroparesis. Peptides 2006;27:1603-1606.

38. Murray CD, Martin NM, Patterson M, et al. Ghrelin enhances gastric emptying in diabetic gastroparesis: a double blind, placebo-controlled crossover study. Gut 2005;54:1693-1698.

39. Cummings DE, Frayo RS, Marmonier C, Aubert R, Chapelot D. Plasma ghrelin levels and hunger scores in humans initiating meals voluntarily without time- and food-related cues. Am J Physiol 2004;287:E297-E304.

40. Lee KJ, Cha DY, Cheon SJ, Yeo M, Cho SW. Plasma ghrelin levels and their relationship with gastric emptying in patients with dysmo- 
tility-like functional dyspepsia. Digestion 2009;80:58-63.

41. Piliponsky AM, Pickholtz D, Gleich GJ, Levi-Schaffer F. Human eosinophils induce histamine release from antigen-activated rat peritoneal mast cells: a possible role for mast cells in late-phase allergic reactions. J Allergy Clin Immunol 2001;107:993-1000.

42. Barbara G, Stanghellini V, De Giorgio R, et al. Activated mast cells in proximity to colonic nerves correlate with abdominal pain in irritable bowel syndrome. Gastroenterology 2004;126:693-702.

43. Lee KJ, Kim YB, Kim JH, Kwon HC, Kim DK, Cho SW. The alteration of enterochromaffin cell, mast cell, and lamina propria $\mathrm{T}$ lymphocyte numbers in irritable bowel syndrome and its relationship with psychological factors. J Gastroenterol Hepatol 2008;23:16891694.

44. Guilarte M, Santos J, de Torres I, et al. Diarrhoea-predominant IBS patients show mast cell activation and hyperplasia in the jejunum. Gut 2007;56:203-209.

45. Rothenberg ME, Hogan SP. The eosinophil. Annu Rev Immunol 2006;24:147-174.

46. Barbara G, Wang B, Stanghellini V, et al. Mast cell-dependent excitation of visceral-nociceptive sensory neurons in irritable bowel syndrome. Gastroenterology 2007;132:26-37.

47. Powell N, Walker MM, Talley NJ. Gastrointestinal eosinophils in health, disease and functional disorders. Nat Rev Gastroenterol Hepatol 2010;7:146-156.

48. Walker MM, Talley NJ, Prabhakar M, et al. Duodenal mastocy- tosis, eosinophilia and intraepithelial lymphocytosis as possible disease markers in the irritable bowel syndrome and functional dyspepsia. Aliment Pharmacol Ther 2009;29:765-773.

49. Martin ST, Collins CG, Fitzgibbon J, Lee G, Quigley EM, O'Sullivan GC. Gastric motor dysfunction: is eosinophilic mural gastritis a causative factor? Eur J Gastroenterol Hepatol 2005;17:983986.

50. Murch S. Allergy and intestinal dysmotility-evidence of genuine causal linkage? Curr Opin Gastroenterol 2006;22:664-668.

51. Hogan SP, Mishra A, Brandt EB, et al. A pathological function for eotaxin and eosinophils in eosinophilic gastrointestinal inflammation. Nat Immunol 2001;2:353-360.

52. Mearin F, Pérez-Oliveras M, Perelló A, et al. Dyspepsia and irritable bowel syndrome after a Salmonella gastroenteritis outbreak: one-year follow-up cohort study. Gastroenterology 2005;129:98-104.

53. Tack J, Demedts I, Dehondt G, et al. Clinical and pathophysiological characteristics of acute-onset functional dyspepsia. Gastroenterology 2002;122:1738-1747.

54. Gargala G, Lecleire S, François A. Duodenal intraepithelial T lymphocytes in patients with functional dyspepsia. World J Gastroenterol 2007;13:2333-2338.

55. Suzuki H. Post-infectious functional dyspepsia - A novel disease entity among functional gastrointestinal disorders - Relation to Helicobacter pylori infection? J Neurogastroenterol Motil 2010;16: 97-98. 